\title{
A Conversation with David Weber
}

Editor's Note: During the April meeting of the ACRL Executive Committee in Chicago, 1 had the opportunity to talk with Datid C. Weber, vicepresident/presidentelect of ACRL, about his rieus on the future of academic librarianship.

Weber has been director of libraries at Stanford University since 1969. He begins his term of office as $43 r d$ president of $A C R L$ at the end of the $A L A$ annual conference in July 1981 .

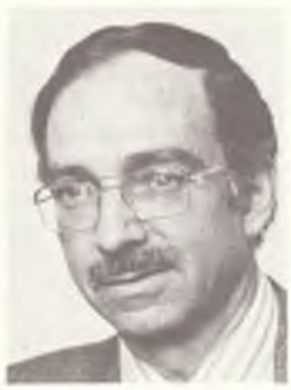

David C. Weber
Ed.: What are the major issues that ACRL will be addressing in the next few years?

Weber: It seems to me that there might be four themes that one could draw out of recent issues. The first will be my effort to maintain the program pace, in the footsteps of Lee Anderson, Penny Abell, and others, and to support the very strong central staff that we have-Julie Virgo and her colleagues here at ACRL headquarters-as well as support the programs of sections, chapters, committees, and the momentum that each of these has. That should be my prime effort.

A second theme is to ensure the fiscal soundness of the association in times of great economic change. Certainly the impact of governmental policy on our own academic institutions and our association is understood to be very strongperhaps stronger than it has been in several decades. The inflationary factors are ones that we will have to pay more attention to than we did in what seemed to be more stable times ten or fifteen vears ago.

Third, I am concerned about the quality of academic and research librarians-drawing into the profession those who will be the academic librarians of the $80^{\circ} \mathrm{s}$ and $90^{\circ} \mathrm{s}$ and beyond, and the leaders in our association and our profession. Deriving from that is the effectiveness of recruitment, the quality of education for librarianship, placement efforts, staff development, career counseling, and other personnel areas which are of considerable importance to us all. The quality of those human resources will have a fundamental impact on our future, both as an association and as practicing professionals in the field.

Fourth, certainly we must look to how we can contribute to shaping academic librarianship as it is needed in response to our clientele over the next $10-20$ years. To me that means recognition of the current forces in librarianship, a recognition of historical developments in the recent past, and an attention to future characteristics--where we are going and how we will get there. That attention to the future certainly encompasses concerns about the basic quality of our services, the nature of our collections, the relationship with our clientele, the working environment within the profession, the financial resources needed to perform effectively our mission, the nature of management of libraries, and the utilization of technology

That doesn't cover everything, but it covers a lot that can challenge the association.

Ed.: How actice a role do you see ACRL taking in shaping the future of academic librarianship?

Weber: That is probably up to each president, each officer, each section and committee chair, to answer for themselves. There will be some difference of opinion. I would hope that ACRL is an active force, an initiator of ideas, providing leadership and coherence and clarity in the field. That does necessitate continuing education programs, a strong publication program, providing a forum for academic librarians all over the country to come together under the aegis of ACRL. ACRL should be active as well as responsive. After all, it is a membership organization and all of us should contribute toward its goals as well as draw from it.

Ed.: One active role $A C R L$ is taking lies in the question of academic status. Do you foresee improvements in this area?

Weber: I think for some institutions it needs to be strongly advanced, and for others it may be quite reasonable as it now is. At Stanford we have a program that most of us believe to be an excellent form of professional standing and recognition. However, it is short of providing librarians professorial rank or all of the perquisites of the teaching faculty. Yet librarians have a position of honor within the academic staff, and are so recognized formally within the university.

The enrollment trends over the next 15-18 years in academic institutions and the economic forces that derive from that could well put several pressures on our profession. There may be fewer positions available, although I am very doubtful that there will be any sharp drop. Some institutions will feel it more than others. The difficulty of bringing new, talented men and women into the field is a problem that we should give a good deal of attention to, just as college and university presidents are concerned about bringing new 
blood into the teaching faculty. I am doubtful that there will be any change of career patterns in the majority of academic institutions.

Ed.: What does it take to be director of a large university library? Is it harder now in the $80^{\circ} \mathrm{s}$ than it was 20 years ago?

Weber: It is commonly said that students are brighter todav and that management is more difficult today, and so on. I am not at all certain that the management of a major academic library is any more difficult now than it was ten or twenty years ago. Thirty years ago I worked as administrative assistant to Keyes D. Metcalf and saw him working as widely and as hard in diverse areas of library management as I do now-utilizing the staff capabilities, solving problems with methods that are regarded today as appropriate, modern methods of university library management. It is true we have somewhat more varied techniques today, and many libraries have much larger collections and staffs and budgets. However, we also have more technical and professional specialists to call upon.

I would urge librarians to develop their professional capabilities as broadly as they can. One may start out as I did as a descriptive cataloger, but in order to build a strong career in leading an academic library, I believe that one needs to have a good understanding of collection development, relationships with faculty and students and administrators, the standards of service, personnel needs, personnel management methods, financing and budgeting, fund raising, and so on.

$E d$ : What made you decide to enter the library profession?

Weber: There is no doubt that it was my father who planted the seed. He was a professor of $\mathrm{En}_{\mathrm{n}}$ glish literature, a very distinguished scholar interested in the development of the college library and its rare book and manuscript collections. Through him I met in our own home people like Fred Anthoensen, Robert B. Downs and James Humphry. There were lots of books in the family-my mother and father were both omniverous readers, scholars and students, often discussing authors and books, words, places, names, at the dinner table. It was therefore a very congenial atmosphere for the formation of an academic librarian.

\section{Bibliographic Instruction}

\section{A Non-Credit/Non-Graded Course at the University of Kansas}

In a continuing effort to determine the best approach(es) for bibliographic instruction at the University of Kansas, Lawrence, reference and instruction librarians are developing a non-credit/ non-graded sequence for students who are interested in learning basic research skills. The course was advertised by posters placed throughout major academic buildings on campus, the student union, and Watson (main) Library. Enrollment and attendance are voluntary: the sequence is open to students at all levels and in all areas of study.

The course, which lasts for seven weeks, meets once a week for one hour and forty-five minutes. Each session covers a predetermined topic (syllabi are made available) and consists of a lecture, relevant demonstrations using handouts and supporting materials, and interactive discussions. The sessions cover the following topics and concerns:
1) Introduction; classification systems; card catalog-Author/Title.

2) Card catalog-Subject; Library of Congress Subject Headings; subject tracings.

3) Periodicals; periodical indexes; our COMCAT for serials.

4) Reference books-dictionaries, encyclopedias, biographical tools, others.

5) Reference books (cont.)-bibliographies.

6) Other materials, including microforms, newspapers, and government documents.

7) Designing a search strategy; other topies; review.

At the conclusion of each of the first six sessions, an assignment sheet for those who wish to follow up the session's coverage with a brief set of exercises, is distributed. Typical questions ask the student to utilize class materials and basic research tools. For example, an exercise following 